UDC 581.143.6:581.2:635.64

DOI: $10.15587 / 2519-8025.2017 .99815$

\title{
INVESTIGATION OF THE INFLUENCE OF SALICYLIC ACID ON THE CAUSES OF BACTERIAL DIAGNOSTICS OF TOMATOES
}

\author{
C)Y. Kolomiets
}

\begin{abstract}
Встановлено антибактеріальний вплив саліцилової кислоти на збудників бактеріального раку, чорної бактеріальної плямистості та бактеріальної крапчастості томатів і потенційні ї̈ можливості в пригніченні розвитку хвороб. Застосування СК знижувало ступінь розвитку бактеріальних хвороб томата на 8-65\% за штучного зараження. Обприскування рослин томатів розчином СК було ефективнішим, ніж замочування коренів
\end{abstract}

Ключові слова: томати, збудники бактеріальних хвороб, саліцилова кислота, антибактеріальна активність, захист рослин

\section{Introduction}

The problem of plant resistance against bacteriosis pathogens is one of the most important in modern horticulture. In this regard, compounds increasing the stability of plant varieties by mobilizing their natural defense mechanisms are increasingly used, in particular salicylic acid (SA).

$\mathrm{SA}$ is one of the key molecules involved in the formation of immune response and systemic induced plant resistance against bacterial diseases. It is accumulated in infected areas of plants, transported by phloem and concentrated in remote uninfected leaves, where, in turn, takes place the expression of protective genes responsible for the structural and functional plant protection from stress [1]. SA participation in the mechanisms of plant resistance against diseases is associated with the induction of the generation of reactive oxygen species (ROS) and stimulation of the synthesis of a number of components related to the pathogenesis of plant components [2]. Among SA-dependent signaling systems there are NADPH-oxidase - SA, acting as an inhibitor of catalase activity and hydrogen peroxide accumulation regulator. NO-synthase - SA promotes NO-induced salicylatedependent formation of mRNA protein PR1, and MAPkinase - SA associated with the induction of the kinase isoforms SIPK and adenyl cyclase system [2].

\section{Literature review}

Bacterial diseases are the most dangerous for tomato plants, which is caused by prolonged latent period of pathogen development, the complexity of the diagnosis in the early infection period, and numerous sources of infection [3]. Despite the minor species composition, pathogens of bacterial diseases have a wide range of host plants, making it difficult to rotate crops in crop rotation, although most of them are confined to the Solanaceae crops. In recent years it has been seen an increasing hazard of bacterial diseases that is associated with the emergence of new, more aggressive strains of pathogenic bacteria, gradual increase in the duration and average temperatures of the growing season, and the monoculture share and genetic uniformity of cultivated varieties [4].

Application of pesticides based on copper compounds for pathogen control in the field or greenhouse conditions are effective only at an early infection stage due to the rapid emergence of bacterial resistance to drugs. Under cover they are recommended seed treating, plant debris removal, and equipment disinfection. In the field in terms of the intensive development of bacterial diseases they use crop rotation with planting tomatoes not earlier than in a season. They are described tomato varieties and hybrids resistant to diseases, but because of racial variability of pathogens they are ineffective in terms of significant disease development [5].

One of the potential ways to activate defense mechanisms of plants against bacterial disease pathogens is the induction of systemic acquired resistance [6]. Classical form of SAR can be caused by virulent, avirulent, and non-pathogenic microorganisms or artificially with the help of chemicals, which are products of intermediate product of the immune response available for plants. These can be salicylic acid (SA), methyl salicylate, 2,6-dichloroisonicotinic acid (INA), jasmonic acid (JA), JA methyl, benzothiazole derivatives, DL-B-aminobutyric and oxalic acids [7]. Exogenous SA is included into the signal path and metabolism of the endogenous SA in plants and induces systems of resistance against biotrophic pathogens, including hypersensitivity and local resistance reaction. In the absence of pathogens SA together with sugars produces nonphytotoxic glycosides, and in response to the infection of plants with pathogens turns into an active form by the action of the glycosidase enzyme [8]. As a result, phloem healthy tissues accumulate SA, which induces the synthesis of pathogen-related PRproteins that destroy the walls and cell membranes of bacteria. This is a major defensive SAR reaction in plants and its main marker.

It is shown that salicylic acid has a stimulating effect on the morphometric characteristics and antioxidant activity of plant-regenerants of the tomato varieties Chaika and Malynovyi Dzvin in terms of bacterial stress caused by Pseudomonas syringae pv. tomato. While the simultaneous action of SA and phytotoxic metabolites of $P$. syringae pv. tomato IS-28, the antioxidant activity of phenols in tomato variety Chaika increased by 4,94 7,04 mcIU-equiv, and of Malynovyi dzvin variety - by 4,86 - 7,16 mcIU-equiv [9]. 


\section{Aim and research problems}

Aim - investigate the ability of the SA to inhibit the growth of strains of Xanthomonas vesicatoria, Pseudomonas syringae pv. tomato and Clavibacter michiganensis subsp. michiganensis in nutrient media and suppress the development of bacterial black spot, bacterial spotting and bacterial cancer in tomato plants in terms of artificial infection.

Research problems:

1) identify the virulence of strains $C$. michiganensis subsp. michiganensis, $X$. vesicatoria and $P$. syringae pv. tomato;

2) investigation of the antibacterial effect of SA on the agents of bacterial cancer, bacterial black spot and bacterial speck;

3) establish the effect of SA on the degree of development of bacterial black spot, bacterial spotting and bacterial cancer on young tomato plants under artificial infection.

\section{Materials and methods}

Virulence of selected strains of $X$. vesicatoria IS-30, IS-31, IS-34, P. syringae pv. tomato IS-28, IS-46 and $C$. michiganensis subsp. michiganensis IS-38, IS-40 in laboratory environment was determined by artificial infection of stalks and leaves of tomato plants by injection. It was deposited a drop of bacterial cell suspension in density of $1 \times 10^{9} \mathrm{CFU} / \mathrm{ml}$ (turbidity standard) and bruised the surface of plants with triple stab. The suspension of bacterial cells was prepared on the day of infection with bacterial mass that has been grown on potato agar for 1-2 days in sterile tap water. For control it was used sterile tap water.

In 7 and 14 days the inoculated plants showed necrosis development around the injection site, browning of vessels in longitudinal and transverse sections, wilting of tops or leaves of plants. Accounting of strains aggression was carried out using the 10-point scale [10]. Strains with pathogenicity from 7 to 9 points were considered aggressive, from 5 to 7 points - of average aggressiveness, and from 5 to 1 point - of low aggressiveness.

SA on bacteria was studied by perforation method [11]. First they were made holes in the middle of thicken potato agar with the help of cork borer. Then, in petri dishes into the holes with the help of sterile removable spouts it was dispensed SA solution at concentrations of $0.5,1.0,2.5,5.0$ and $10 \mathrm{mg} / \mathrm{l}$. After that, it was radially plated one-day suspension of bacteria cells with titer of $10^{9} \mathrm{CFU} / \mathrm{ml}$. The plates had been incubated for $48 \mathrm{~h}$ at $28 \pm 1{ }^{\circ} \mathrm{C}$. Antibacterial effect of SA was assessed by diameter of the zone with no bacterial growth.

Tomato seeds of Chaika variety were planted in boxes in sterile substrate mixture of soil and sand (4:1) and germinated in greenhouse conditions. After the appearance of seedlings, the plants were transplanted into individual containers. The treatment of young tomato seedlings with SA was conducted at the stage of replanting; for this, roots were dipped into SA solution and kept there for 1 hour. The repetition of experiments was four times. In 28 days tomato seedlings were sprayed with SA solution. Artificial infection with pathogens was conducted in 30 days after pricking in. The level of disease development was assessed in 7 and 14 days after artificial infection with pathogens by the following scale:

$-0 \%$ - the plant is not affected;

$-1-5 \%$ - individual spots on the leaves at the injection site;

$-6-10 \%-1 / 4$ of leaf surface is infected is covered with lesions;

$-11-25 \%$ - spots which can be counted, lesions cover not more than $1 / 3$ of the surface of the leaves and stems;

$-26-50 \%-$ lesions cover $2 / 3$ of the surface of the leaves and stems;

$-51-75 \%$ - wilting of leaf tops of the plants, stems of plants are greatly affected [12].

Statistical analysis of the results was performed using application software package STATISTICA v.6.0.

\section{Results of the research}

As a result of artificial infection of young tomato seedlings it was found that isolated strains $X$. vesicatoria IS-30, IS-31, IS-34, P. syringae pv. tomato IS-28, IS-46, and $C$. michiganensis subsp. michiganensis IS-38, IS-40 result in the appearance of symptoms of plant infestation. Symptoms of infection, which occurred in 3-4 days, were marked by the appearance of necrotic spots of irregular shape on the leaves, twisting and withering of the top. The most aggressive strains proved to be $P$. syringae pv. tomato IS-28, $X$. vesicatoria IS-30 and C. michiganensis subsp. michiganensis IS-38, aggressiveness of which was 7-9 points. Average aggressive strains were $X$. vesicatoria IS-31 and C. michiganensis subsp. michiganensis IS-40, with aggressiveness of 5 and 6 points (Fig. 1, 2).

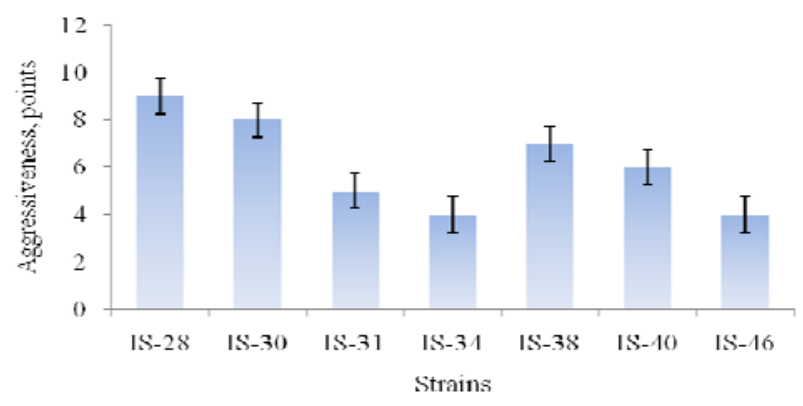

Fig. 1. Manifestation of aggressiveness of isolated strains during artificial infection of young tomato plants of Chaika variety

SA concentrations show different antibacterial activity against selected strains due to their characteristics (Table 1). The diameter of the zone with no growth increased with increasing concentrations of SA, which showed high antibacterial activity against bacterial cancer $C$. michiganensis subsp. michiganensis and bacterial black spotting $X$. vesicatoria, and no growth zone diameter ranged from 70 to $80 \mathrm{~mm}$. Somewhat less antibacterial activity of SA was observed against strains $P$. syringae pv. tomato, growth inhibition zones of which did not exceed $14 \mathrm{~mm}$. Indicated that SA antibacterial properties associated primarily with its effect on the cell walls of microorganisms as of chelating agent [13]. 


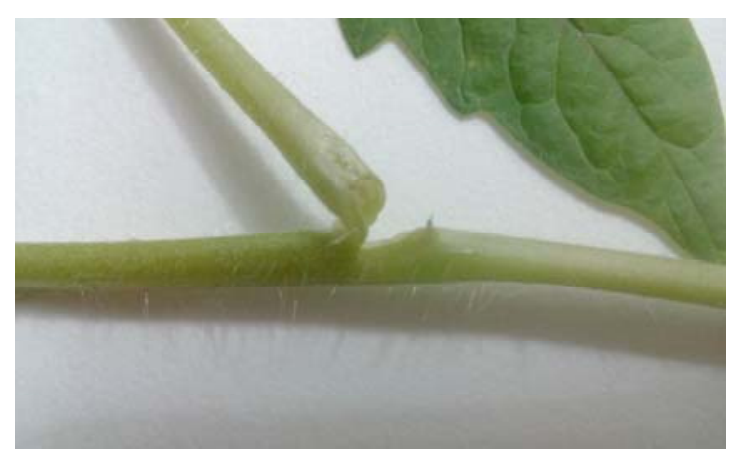

$a$

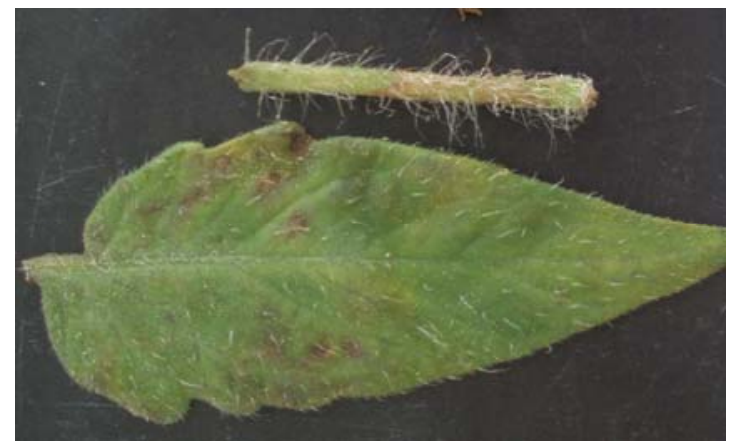

b

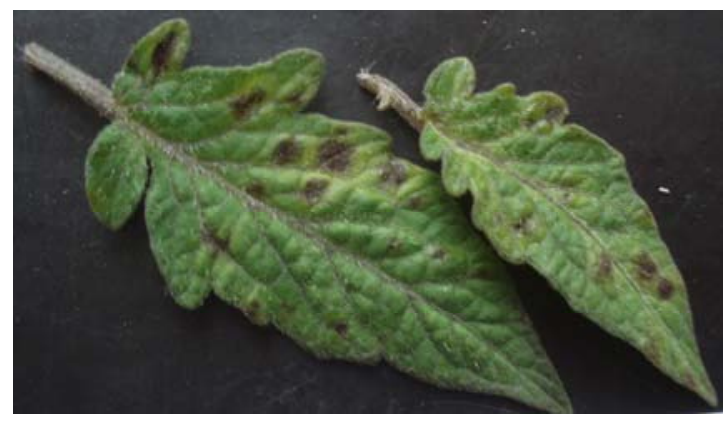

$c$

Fig. 2. Manifestation on the leaf blades and stalk of tomato plants of the Chaika variety of symptoms caused by pathogens of bacterial diseases: $a-C$. michiganensis subsp. michiganensis, $b-X$. vesicatoria, $c-P$. syringae $\mathrm{pv}$. tomato

In the case of gram-negative bacteria, the primary target of action appears lipopolysaccharide, which is a part of the outer membrane and is negatively charged, which gives hydrophilic properties to the surface of microbial cells, due to which it becomes complicated the penetration into hydrophobic molecules with antibacterial action. Interaction of chelating agent with LPS causes destabilization of the external structures of gram-negative bacteria and substantially reduces its barrier function, resulting in bacterial cells becoming more inclined to action of other antimicrobial agents that are not able to penetrate through native membrane $[14,15]$. The main targets of grampositive bacteria are teichoic acids, the negative charge of which is provided by numerous remains of phosphoric acid. They are in a complex with bivalent metal ions and as the result of interaction with the chelating agent it takes place a violation of the ionic balance of cells. Teichoic acids in composition of cell walls are also linked with positively charged autolysin proteins that play an important role in murein degradation. Competitive displacement of excessive amount of autolysins from their complex by chelating agent causes uncontrolled cell wall lysis [14]. Under the influence of chelating agents it also plasmolemma permeability, occur conformational changes of membrane proteins that are involved in the transfer of electrons during aerobic respiration and control the functioning of the electron transport chain $[14,16]$.

The use of SA reduces the degree of the development of bacterial black spot, bacterial spotting and bacterial cancer in young tomato plants under artificial infection (Table 2). In the infected leaves of untreated with SA plants the disease symptoms manifested on the second day as light brown spots with yellow rim, which increased at the end of the experiment up to the large light-brown necrosis. It was recorded that on the second day after infection of tomato plants, the ones treated with SA, had no obvious signs of lesions when compared to the control plants that had not been treated with SA.

On the seventh day on the leaves of the control group of tomatoes they were observed light-brown dry spots, the degree of destruction of leaves ranged from 26 to $50 \%$. In the plants treated with SA these symptoms were observed slightly, evidenced by the appearance of compared smaller dark brown spots on the leaves, and lesions area was $5-15 \%$ of lamina.

In plants untreated with SA and infected with $C$. michiganensis subsp. michiganensis in a week it was found pith necrosis on the cut of the stem, and after 2 weeks the degree of lesions was $50-75 \%$. While in treated tomato plants on the 7 th day they were not observed obvious symptoms infestations, and on the 14th day they were affected not more than $50 \%$ of tissues.

Table 1

Antibacterial activity of salicylic acid against pathogens bacterial diseases of tomatoes

\begin{tabular}{|c|c|c|c|c|c|c|c|}
\hline \multirow{2}{*}{$\begin{array}{c}\text { Concentration SA, } \\
\mathrm{mg} / 1\end{array}$} & \multicolumn{5}{|c|}{ The diameter of the zone of no growth (mm) of the isolated strains } \\
around wells with a solution of SA \\
\cline { 2 - 8 } & \multicolumn{3}{|c|}{ X. vesicatoria } & P. syringae pv. tomato & \multicolumn{2}{c|}{$\begin{array}{c}\text { C. michiganensis subsp. } \\
\text { michiganensis }\end{array}$} \\
\cline { 2 - 8 } & IS-30 & IS-31 & IS-34 & IS-28 & IS-46 & IS-38 & IS-40 \\
\hline 0,5 & $24 \pm 1$ & $22 \pm 2$ & $24 \pm 2$ & $2 \pm 1$ & $2 \pm 1$ & $15 \pm 2$ & $12 \pm 2$ \\
\hline 1,0 & $36 \pm 2$ & $34 \pm 1$ & $38 \pm 4$ & $4 \pm 1$ & $4 \pm 1$ & $20 \pm 4$ & $26 \pm 3$ \\
\hline 2,5 & $42 \pm 3$ & $40 \pm 3$ & $44 \pm 2$ & $8 \pm 2$ & $6 \pm 2$ & $45 \pm 3$ & $47 \pm 4$ \\
\hline 5,0 & $60 \pm 2$ & $60 \pm 2$ & $62 \pm 3$ & $10 \pm 3$ & $8 \pm 2$ & $63 \pm 4$ & $66 \pm 2$ \\
\hline 10,0 & $80 \pm 3$ & $70 \pm 4$ & $80 \pm 4$ & $14 \pm 4$ & $12 \pm 2$ & $70 \pm 4$ & $60 \pm 2$ \\
\hline control & $0 \pm 0$ & $0 \pm 0$ & $0 \pm 0$ & $0 \pm 0$ & $0 \pm 0$ & $0 \pm 0$ & $0 \pm 0$ \\
\hline
\end{tabular}


Table 2

The effect of salicylic acid on the degree of development of the disease in the artificial defeat of tomato plants of the Chaika variety

\begin{tabular}{|c|c|c|c|c|c|c|c|c|c|c|c|c|}
\hline \multirow{3}{*}{$\begin{array}{l}\text { Concent- } \\
\text { ration } \\
\mathrm{SA}, \mathrm{mg} / 1\end{array}$} & \multicolumn{4}{|c|}{$\begin{array}{l}\text { Degree of development of bacterial } \\
\text { black spot }(\%) \text { during processing }\end{array}$} & \multicolumn{4}{|c|}{$\begin{array}{l}\text { Degree of development of bacterial } \\
\text { speck }(\%) \text { during processing }\end{array}$} & \multicolumn{4}{|c|}{$\begin{array}{l}\text { Degree of development of bacte- } \\
\text { rial cancer }(\%) \text { during processing }\end{array}$} \\
\hline & \multicolumn{2}{|c|}{ roots } & \multicolumn{2}{|c|}{ leaves } & \multicolumn{2}{|c|}{ roots } & \multicolumn{2}{|c|}{ leaves } & \multicolumn{2}{|c|}{ roots } & \multicolumn{2}{|c|}{ leaves } \\
\hline & $\begin{array}{c}7 \\
\text { days }\end{array}$ & $\begin{array}{c}14 \\
\text { days }\end{array}$ & $\begin{array}{c}7 \\
\text { days }\end{array}$ & $\begin{array}{c}14 \\
\text { days }\end{array}$ & $\begin{array}{c}7 \\
\text { days }\end{array}$ & $\begin{array}{c}14 \\
\text { days }\end{array}$ & $\begin{array}{c}7 \\
\text { days }\end{array}$ & $\begin{array}{c}14 \\
\text { days }\end{array}$ & $\begin{array}{c}7 \\
\text { days }\end{array}$ & $\begin{array}{c}14 \\
\text { days }\end{array}$ & $\begin{array}{c}7 \\
\text { days }\end{array}$ & $\begin{array}{c}14 \\
\text { days }\end{array}$ \\
\hline 0,5 & $15 \pm 2$ & $50 \pm 4$ & $12 \pm 2$ & $45 \pm 4$ & $15 \pm 2$ & $50 \pm 4$ & $13 \pm 2$ & $45 \pm 2$ & $3 \pm 1$ & $25 \pm 2$ & $2 \pm 1$ & $23 \pm 1$ \\
\hline 1,0 & $12 \pm 2$ & $45 \pm 2$ & $10 \pm 2$ & $40 \pm 2$ & $12 \pm 1$ & $45 \pm 2$ & $10 \pm 1$ & $40 \pm 2$ & $3 \pm 1$ & $22 \pm 1$ & $2 \pm 1$ & $20 \pm 1$ \\
\hline 2,5 & $12 \pm 2$ & $43 \pm 2$ & $10 \pm 1$ & $40 \pm 2$ & $8 \pm 2$ & $36 \pm 2$ & $8 \pm 1$ & $30 \pm 1$ & $2 \pm 1$ & $18 \pm 2$ & $2 \pm 1$ & $15 \pm 2$ \\
\hline 5,0 & $10 \pm 2$ & $40 \pm 1$ & $7 \pm 1$ & $35 \pm 1$ & $8 \pm 1$ & $30 \pm 2$ & $7 \pm 2$ & $25 \pm 1$ & $2 \pm 1$ & $15 \pm 1$ & $1 \pm 1$ & $10 \pm 1$ \\
\hline 10,0 & $5 \pm 1$ & $30 \pm 2$ & $5 \pm 1$ & $25 \pm 1$ & $7 \pm 1$ & $20 \pm 2$ & $5 \pm 1$ & $18 \pm 2$ & $1 \pm 1$ & $12 \pm 1$ & $1 \pm 1$ & $10 \pm 1$ \\
\hline control & $26 \pm 2$ & $58 \pm 2$ & $30 \pm 2$ & $60 \pm 2$ & $45 \pm 4$ & $68 \pm 2$ & $50 \pm 4$ & $72 \pm 2$ & $50 \pm 1$ & $70 \pm 2$ & $45 \pm 2$ & $75 \pm 2$ \\
\hline
\end{tabular}

Spraying of tomato plants with SA solution was more effective than soaking of roots. Increase of SA concentrations increased the degree of disease inhibition. The mechanism of induction of systemic acquired resistance of SA is associated with the synthesis of compounds of pro- and antioxidant systems, which inhibit the growth and spread of phyto-pathogenic bacteria in plants. It was established that SA increases resistance of cucumbers against Pseudomonas syringae pv. lachrymanus [17], of tobacco - against Erwinia carotovora [18], of potatoes - against E. carotovora subsp. carotovora, Ralstonia solanacearum [13] and common scab pathogen Streptomyces scabies [13]. It was proved high efficiency of SA as of antioxidant against bacterial and fungal diseases.

SA compounds are used in crop production. On the basis of analogous the firm "Novartis" (Switzerland) has developed and implemented the drug Bion (active substance benzothiadiazole (benzo-(1,2,3)-thiadiazole-7carbotionic acid S-metyl ester), the company "BASF" Strobi that are effective against infectious diseases of Cucurbitaceae, Solanaceae and cereals [19]. However, despite intensive research, the use of SA and its derivatives is limited because between stimulating and phyto- toxic concentrations there are very small differences. Application of SA is one of the parts of a complex system, which leads to increased resistance of plants against tomato bacterial spotting, but its amount does not exceed a certain concentration threshold, which is required for activation of protection systems and optimal functioning of plants [9]. In the absence of infection the existing SA concentrations did not cause the visual changes in the morphology of leaves of young tomato plants.

\section{Conclusions}

1. The most aggressive strains proved to be $P$. syringae pv. tomato IS-28, $X$. vesicatoria IS-30 and C. michiganensis subsp. michiganensis IS-38, aggressiveness of which was 7-9 points.

2. SA solutions showed high antibacterial activity against pathogens of bacterial cancer C. michiganensis subsp. michiganensis and bacterial black spot $X$. vesicatoria with no growth zone of $70-80 \mathrm{~mm}$.

3. Spraying of tomato plants with SA solution was more effective than soaking the roots. Increased SA concentrations caused the increased effectiveness of inhibition of tomato plants bacterial diseases.

\section{References}

1. Vasyukova, N. I. Induced plant resistance and salicylic acid [Text] / N. I. Vasyukova, O. L. Ozeretskovskaya // Applied biochemistry and microbiology. - 2007. - Vol. 43, Issue 4. - P. 367-373. doi: 10.1134/s0003683807040011

2. Kolupaev, Yu. E. Stress-protective effects of salicylic acid and its structural analogy [Text] / Yu. E. Kolupaev, T. O. Yastreb // Physiology and biochemistry of cultivated plants. - 2013. - Vol. 45, Issue 2. - P. 113-126.

3. Hvozdiak, R. I. Phytopathogenic bacteria. Bacterial plant diseases [Text]: monograph / R. I. Hvozdiak, L. A. Pasichnyk, L. M. Yakovleva et. al.; ed. V. P. Patyka. - Kyiv: TOV NVP «Interservice», 2011. - 444 p.

4. Ignatov, A. I. New pathogens of bacterial infections and the prognosis of their spread in Russia [Text] / A. I. Ignatov, N. V. Punina, E. V. Matveeva, K. P. Kornev et. al. // Protection and quarantine of plants. - 2009. - Vol. 4. - P. 38-40.

5. Bykova, G. A. Features of protection of vegetable crops in greenhouses against bacteriosis [Text] / G. A. Bykova, E. B. Belykh // Protection and quarantine of plants. - 2011. - Vol. 3. - P. 32-35.

6. Shafikova, T. N. Molecular-genetic aspects of plant immunity to phytopathogenic bacteria and fungi [Text] / T. N. Shafikova, Yu. V. Omelichkina // Plant Physiology. - 2015. - Vol. 62, Issue 5. - P. 571-585. doi: 10.1134/ s1021443715050143

7. Plotnikova, L. Y. Effect of benzothiadiazole, an inducer of systemic acquired resistance, on the pathogenesis of wheat brown rust [Text] / L. Y. Plotnikova // Russian Journal of Plant Physiology. - 2009. - Vol. 56, Issue 4. - P. 517-526. doi: $10.1134 / \mathrm{s} 1021443709040116$

8. Poliksenova, V. D. Induced resistance of plants to pathogens and abiotic stress factors [Text] / V. D. Poliksenova // Bulletin BSU. - 2009. - Vol. 1. - P. 48-60.

9. Kolomiiets, $\mathrm{Yu}$. V. The effect of salicylic acid on the components of the antioxidant system of tomato plants in conditions of bacterial stress [Text] / Yu. V. Kolomiiets, I. P. Hryhoriuk, L. M. Butsenko // Quarantine and plant protection. - 2016. - Vol. 1112. - P. 7-11.

10. Zakharova, O. M. Bacterial diseases of rape [Text] / O. M. Zakharova, M. D. Melnychuk, L. A. Dankevych, V. P. Patyka // Microbiological Journal. - 2012. - Vol. 74, Issue 6. - P. 46-52. 
11. Egorov, N. S. Fundamentals of theory of antibiotics [Text] / N. S. Egorov. - Moscow: Publish MNU Nauka, 2004. - 528 p.

12. Hryhoriuk, I. P. Identification of the agent of bacterial speck of tomato plants Pseudomonas syringae pv. Tomato [Text]: scientific and methodological recommendations / I. P. Hryhoriuk, V. P. Patyka, Yu. V. Kolomiiets, L. M. Butsenko et. al. - Kyiv: Komprint, 2016. -40 p.

13. AL-Saleh, M. A. Pathogenic variability among five bacterial isolates of Xanthomonas campestris pv. vesicatoria, causing spot disease on tomato and their response to salicylic acid [Text] / M. A. AL-Saleh // Journal of the Saudi Society of Agricultural Sciences. - 2011. - Vol. 10, Issue 1. - P. 47-51. doi: 10.1016/j.jssas.2010.08.001

14. Kulikov, S. N. Antibacterial activity of chitosan and its derivatives [Electronic resource] / S. N. Kulikov, Yu. A. Tyurin, A. V. Ilina, A. N. Levov, S. A. Lopatyn, V. P. Varlamov // Proceedings of the Belarusian State University. - 2009. - Vol. 4, Issue 1. - Available at: http://elib.bsu.by/handle/123456789/16155

15. Liu, H. Chitosan kills bacteria through cell membrane damage [Text] / H. Liu, Y. Du, X. Wang, L. Sun // International Journal of Food Microbiology. - 2004. - Vol. 95, Issue 2. - P. 147-155. doi: 10.1016/j.ijfoodmicro.2004.01.022

16. Raafat, D. Insight into the mode of action of chitosan as an antibacterial compound [Text] / D. Raafat, K. Bargen, A. Haas, H.-G. Sahl // Applied and Environmental Microbiology. - 2008. - Vol. 74, Issue 12. - P. 3764-3773. doi: 10.1128/ aem.00453-08

17. Rasmussen, J. B. Systemic induction of salicylic acid accumulation in cucumber after inoculation with Pseudomonas syringae [Text] / J. B. Rasmussen, R. Hammerschmidt, M. N. Zook // Plant Physiology. - 1991. - Vol. 97, Issue 4. - P. 1342-1347. doi: $10.1104 /$ pp.97.4.1342

18. Palva, T. K. Salicylic acid induced resistance to Erwinia carotovora subsp. carotovora in Tobacco [Text] / T. K. Palva, M. Huntig, P. Saindrenan, E. T. Palva // Molecular Plant-Microbe Interactions. - 1994. - Vol. 7, Issue 3. - P. 356-363. doi: 10.1094/ mpmi-7-0356

19. Tyuterev, S. L. Ecologically safe inductors of plant resistance to diseases and physiological stresses [Text] / S. L. Tyuterev // Journal of Plant Protection. - 2015. - Vol. 1 (83). - P. 3-13.

Рекомендовано до публікачії д-р біол. наук, професор, академік НААН України Федоренком В. П. Дата надходження рукопису 06.03.2017

Kolomiets Yulia, PhD, Associate Professor, Department of environmental biotechnology and biodiversity, National University of Life and Environmental Sciences of Ukraine, Geroyiv Oborony str., 15, Kyiv, Ukraine, 03041

E-mail: julyja@i.ua

УДК 577.151.042:616-056.52:615.322

\section{ДОСЛІДЖЕННЯ ВПЛИВУ TRIGONELLA FOENUM GRAECUM L. НА АКТИВНІСТЬ ФЕРМЕНТІВ АНТИОКСИДАНТНОГО ЗАХИСТУ ЗА УМОВ ДІЕТІНДУКОВАНОГО ОЖИРІННЯ У ЩУРІВ}

\section{(C) В. В. Конопельнюк}

Встановлено, наростання маси жирової тканини та порушення функиіонування антиоксидантної системи в тварин з ожирінням індукованим споживанням висококалорійної дієти. Введення 2 \% дрібнодисперсного порошку насіння Trigonella foепuт graecum L. в висококалорійний корм привело до нормалізачії всіх досліджуваних показників (жирової тканини та активності ферментів). Такі результати свідчать про профілактичну дію насіння фенугреку

Ключові слова: фенугрек, ожиріння, висококалорійна дієта, щури, жирова тканина, супероксиддисмутаза, каталаза, глутатіонпероксидаза

\section{1. Вступ}

Ожиріння є одним з найбільш поширених хронічних захворювань, а також $є$ однією 3 провідних проблем сучасності, пов'язаних зі здоров'ям людства. У 2016 році було оприлюднено дослідження, в якому показано, що до 2025 року на ожиріння будуть страждати майже $20 \%$ населення Землі [1]. В Україні, за статистикою ВООЗ, 53 \% людей мають зайву вагу, 20 \% страждають на ожиріння та кожен другий знаходиться в зоні ризику [2]. Розвитку ожиріння сприяють зміни в способі життя людей (малорухомий спосіб життя, зростання в раціоні хар- чування вуглеводів та жирів, неправильний режим харчування, що характеризується надмірним накопиченням у жировій тканині триацилгліцеролів).

\section{2. Літературний огляд}

Надмірне накопичення жиру в жировій тканині є результатом хронічного дисбалансу між споживанням та витратою енергії [3, 4]. Раніше жирова тканина розглядалася, як тканина 3 невеликою кількістю метаболічних функцій, проте сьогодні відомо, що жирова тканина є метаболічно активним органом [5]. Деякі дослідники показали взаємозв'язок між роз- 